\title{
Interactive comment on "Global mean surface temperature and climate sensitivity of the EECO, PETM and latest Paleocene" by Gordon N. Inglis et al.
}

Gordon N. Inglis et al.

gordon.inglis@soton.ac.uk

Received and published: 5 June 2020

Please see our attached PDF supplement for the response to Reviewer 2.

Please also note the supplement to this comment:

https://www.clim-past-discuss.net/cp-2019-167/cp-2019-167-AC2-supplement.pdf

Interactive comment on Clim. Past Discuss., https://doi.org/10.5194/cp-2019-167, 2020. 